\title{
LACTATE DEHYDROGENASE ISOENZYMES IN RAT UTERUS: CHANGES DURING PREGNANCY
}

\author{
L. J. BATTELLINO, J. SABULSKY aNd A. BLANCO \\ Cátedra de Quimica Biológica, Facultades de Medicina y Odontología, \\ Universidad Nacional de Córdoba, Córdoba, Argentina
}

(Received 20th July 1970)

\begin{abstract}
Summary. Total lactate dehydrogenase-specific activity and concentration of isoenzymes were determined on extracts of rat uterus at different stages of pregnancy, during the oestrous cycle and after ovariectomy.

Total enzymatic activity increased during pregnancy. The rise was evident by the 5 th day and continued steadily until the 14 th day, when it attained maximal values. These high values were maintained up to the end of pregnancy and fell to the level of controls 4 days after parturition.

The changes in enzyme activity were entirely due to variations in the amount of Isoenzymes $5\left(\mathrm{~A}_{4}\right)$ and $4\left(\mathrm{~A}_{3} \mathrm{~B}_{1}\right)$. The other three molecular forms were not modified

Total specific activity and Isoenzymes 5 and 4 were diminished 20 days after ovariectomy.
\end{abstract}

\section{INTRODUCTION}

The five lactate dehydrogenase (L-lactate: NAD oxidoreductase, EC 1.1.1.27) (LDH) isoenzymes found in most tissues of mammals and birds are tetramers formed by the association of two polypeptide units (A, M or 'muscle type' and B, H or 'heart type'-Markert, 1962; Cahn, Kaplan, Levine \& Zwilling, 1962). These isoenzymes are numbered according to their electrophoretic mobility, beginning with the fraction nearest the anode. The polypeptide composition assigned to each of the molecular forms is the following: LDH-1: $\mathrm{B}_{4} ; \mathrm{LDH}-2$ : $A_{1} B_{3} ; L D H-3: A_{2} B_{3} ; L D H-4: A_{3} B_{1}$ and LDH-5: $A_{4}$.

The synthesis of $\mathrm{A}$ and $\mathrm{B}$ polypeptides is under the control of different genetic loci ( $a$ and $b$ ) and the isoenzymes are formed by random association of those units (Markert, 1963, 1968). Thus, the final pattern of a given tissue reflects the relative activity of the a and $b$ genes. In heart, for example, Isoenzymes 1 and 2 are the most abundant because $B$ chains would be predominantly synthesized. On the other hand, in skeletal muscle, LDH-5 is the most prominent fraction because $A$ units would be produced at a much higher rate.

Kinetic studies have demonstrated that LDH isoenzymes with predominance of B polypeptides (LDH-1 and -2) are inhibited by high concentrations of substrate or product, while isoenzymes richer in A chains (LDH-5 and -4) are 
resistant to that inhibition (Plagemann, Gregory \& Wróblewski, 1960; Stambaugh \& Post, 1966; Kaplan, Everse \& Admiraal, 1968). Cahn et al. (1962) assigned functional significance to those observations. The isoenzyme LDH-5 is best suited to work in anaerobic conditions, when lactate accumulates, while LDH-1 favours an aerobic type of metabolism.

It is possible, then, for a tissue to adjust the isoenzymic complement to its particular metabolic requirements by regulating the activity of the genes for $\mathrm{A}$ and $B$ units.

Certain tissues change their metabolic needs during development or in different physiological conditions. The uterus, for example, must attain an extraordinary activity during parturition. The question is whether the relative composition of $\mathrm{LDH}$ isoenzymes is modified in accordance with those special needs.

Previous observations suggested that this would be the case (Richterich, Schafroth, Aebi \& Vogdt, 1963; Biron, 1964) and we decided to undertake a more detailed study of the evolution of $\mathrm{LDH}$ isoenzymes in rat uterus at different stages of pregnancy.

\section{MATERIALS AND METHODS}

Virgin female Sprague Dawley rats weighing about $200 \mathrm{~g}$ were mated in individual cages during 2 days. The appearance of a vaginal plug was considered to be a sign of fecundation and the time of its appearance was recorded as the initiation of pregnancy.

Animals were killed by decapitation at the 5 th, 8 th, 14 th, 17 th and 21 st day of pregnancy and 4 days after parturition. The uterus was removed immediately and embryos and foetuses were separated. The tissue was repeatedly washed

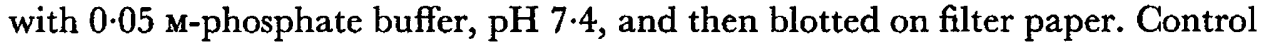
animals were virgin rats of the same age as those used for the experiment. The stage of the oestrous cycle was determined from vaginal smears.

In another group of virgin rats, ovariectomy was performed under ether anaesthesia. These animals were killed 20 days after the operation and the uterus was removed as already described.

\section{Homogenates}

The uterus was minced with scissors and homogenized in four parts $(1: 4$,

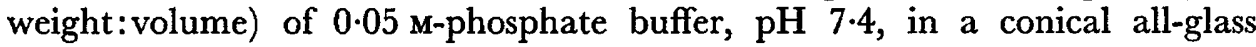
homogenizer. The suspension was centrifuged at 105,000 $\mathrm{g}$ for $30 \mathrm{~min}$. The supernatant was used for electrophoresis and enzymatic activity determinations.

\section{Electrophoresis}

All homogenates were diluted with $0.05 \mathrm{M}$-phosphate buffer to obtain the same total LDH-activity/ml. Electrophoresis was carried out with the vertical technique of Smithies (1959) as described by Battellino, Ramos Jaime \& Blanco (1968).

After electrophoresis, LDH activity was detected on the starch slab by staining with the method used by Blanco, Zinkham \& Kupchyk (1964). The relative 
concentrations of isoenzymes were determined by densitometry after rendering the stained gel strips transparent with a glycerin jelly, as proposed by Johnson (1964).

\section{Lactate dehydrogenase assays}

Enzymatic activity was determined by the method of Wróblewski \& La Due (1955). This is based on a reduction of pyruvate in the presence of NADH resulting in changes of optical density at $340 \mathrm{~nm}$. These changes were recorded at 1 -min intervals for $6 \mathrm{~min}$. Assays were carried out at $25^{\circ} \mathrm{C}$. Homogenates were diluted with $0.05 \mathrm{M}$-phosphate buffer, $\mathrm{pH} 7 \cdot 4$, to obtain a final $\Delta E_{340}$ of 0.030 to $0.040 / \mathrm{min}$.

\section{Protein determination}

Total proteins in the extracts were determined by the method of Lowry, Rosebrough, Farr \& Randall (1951) using crystalline bovine albumin as standard.

\section{Purification of Isoenzymes 1 and 5}

Separation and partial purification of LDH Isoenzyme 1 from heart and Isoenzyme 5 from liver were performed as indicated elsewhere (Battellino et al., 1968).

\section{RESULTS}

Specific activity of lactate dehydrogenase in rat uterus

Evolution during the oestrous cycle. There were no significant changes of LDHspecific activity at the different stages of the cycle.

Evolution during pregnancy. A rise of $\mathrm{LDH}$ activity was already evident by the 5th day of pregnancy and increased progressively to reach a maximum on the 14th day. From this moment, values about twice as high as those of controls were maintained without change until the end of pregnancy. After parturition, the activity decreased rapidly and by 4 days post partum, it was almost at the same level as that of the controls (see Table 1).

Effect of ovariectomy. The activity of $\mathrm{LDH}$ decreased significantly 20 days after ovariectomy (Table 1).

\section{Relative concentration of lactate dehydrogenase isoenzymes}

Evolution during the oestrous cycle. There were no changes in the relative distribution of enzymatic activity between the five isoenzymes at the different stages of the cycle.

Evolution during pregnancy. There was a shift in the relative concentration of enzymatic activity toward the cathodic isoenzymes (LDH-4 and -5) as shown in Plate 1. This shift was already detected in patterns of extracts from the uterus on the 5th day of pregnancy and was marked by the 14th day, and thereafter. If the results are expressed in terms of specific activity (Table 2), it can be seen that LDH-1, -2 and -3 did not change significantly. The increase of enzymatic 
activity resulted from the rise in $\mathrm{LDH}-4$ and -5 isoenzymes. The activity of LDH-5 was still increased 4 days after parturition.

Effect of ovariectomy. Patterns of extracts from rat uterus 20 days after ovariectomy showed a shift of enzymatic activity toward the anodic isozymes LDH-1 and -2 (Plate 1). Specific activities of LDH-1, -2 and -3 were not different from those of controls but LDH-4 and -5 decreased significantly (Table 2).

TABLE 1

SPEGIFIC AGTIVITY OF LAGTATE DEHYDROGENASE IN RAT UTERUS

\begin{tabular}{l|c|cc}
\hline & $\begin{array}{c}\text { No. of } \\
\text { cases }\end{array}$ & \multicolumn{2}{|c}{ Units* $\times g$ protein } \\
\hline Control & 25 & $568 \pm 38$ \\
5-day pregnancy & 10 & $652 \pm 41 \quad P<0.02$ \\
8-day pregnancy & 10 & $800 \pm 31 \quad P<0.01$ \\
14-day pregnancy & 10 & $1033 \pm 65 \quad P<0.01$ \\
17-day pregnancy & 10 & $1035 \pm 55$ & $P<0.01$ \\
21-day pregnancy & 10 & $1017 \pm 49 \quad P<0.01$ \\
4days post partum & 10 & $623 \pm 28$ & $P<0.05$ \\
Ovariectomized & 5 & $442 \pm 24 \quad P<0.01$ \\
\hline
\end{tabular}

Final concentration of pyruvate in the assay mixture was $0.8 \mathrm{~mm}$, otherwise as in Text-fig. 1. Percentage of maximal activity at this concentration of substrate was identical for LDH-1 and LDH-5 (about 90\%).

* One unit is defined as the amount of enzyme necessary to produce a $\Delta E_{340}$ of $2 \cdot 07 / \mathrm{min}$ in the assay conditions.

TABLE 2

CONGENTRATION OF LAGTATE DEHYDROGENASE ISOENZYMES IN RAT UTERUS

\begin{tabular}{|c|c|c|c|c|c|c|c|}
\hline & $L D H-1$ & $L D H-2$ & $L D H-3$ & \multicolumn{2}{|c|}{$L D H-4$} & \multicolumn{2}{|c|}{$L D H-5$} \\
\hline $\begin{array}{l}\text { Control } \\
\text { 5-day pregnancy } \\
\text { 8-day pregnancy } \\
\text { 14-day pregnancy } \\
\text { 17-day pregnancy } \\
\text { 21-day pregnancy } \\
4 \text { days post partum } \\
\text { Ovariectomized }\end{array}$ & $\begin{array}{l}90 \pm 7 \\
85 \pm 10 \\
84 \pm 9 \\
83 \pm 7 \\
80 \pm 9 \\
84 \pm 11 \\
94 \pm 8 \\
83 \pm 9\end{array}$ & $\begin{array}{l}75 \pm 11 \\
77 \pm 6 \\
80 \pm 12 \\
84 \pm 10 \\
85 \pm 10 \\
80 \pm 12 \\
77 \pm 10 \\
74 \pm 12\end{array}$ & $\begin{array}{l}78 \pm 11 \\
82 \pm 9 \\
89 \pm 13 \\
94 \pm 12 \\
94 \pm 15 \\
92 \pm 13 \\
86 \pm 12 \\
70 \pm 7\end{array}$ & $\begin{array}{l}160 \pm 23 \\
201 \pm 17 \\
260 \pm 27 \\
350 \pm 36 \\
357 \pm 21 \\
350 \pm 32 \\
180 \pm 15 \\
105 \pm 16\end{array}$ & $\begin{array}{l}P<0.01 \\
P<0.01 \\
P<0.01 \\
P<0.01 \\
P<0.01 \\
P<0.01\end{array}$ & $\begin{array}{l}165 \pm 15 \\
207 \pm 14 \\
287 \pm 33 \\
422 \pm 28 \\
419 \pm 21 \\
412 \pm 27 \\
186 \pm 13 \\
110 \pm 17\end{array}$ & $\begin{array}{l}P<0.01 \\
P<0.01 \\
P<0.01 \\
P<0.01 \\
P<0.01 \\
P<0.02 \\
P<0.01\end{array}$ \\
\hline
\end{tabular}

Values expressed in Units/g of total protein.

Number of cases for each group identical to those in Table 1.

\section{Effect of pyruvate concentration upon $L D H$ activity of uterine homogenates}

Activity of LDH-1 and LDH-5 purified from rat tissues was studied at different concentrations of pyruvate. The results were similar to those repeatedly obtained by many authors for other species. The isoenzyme, LDH-1, was inhibited by high concentrations of substrate that did not affect the activity of LDH-5 to the same degree. In Table 3 , the ratios of LDH activity determined at two concentrations of pyruvate $(0.2 \mathrm{~mm}$ and $10 \mathrm{~mm})$ and in Text-fig. 1 , the 


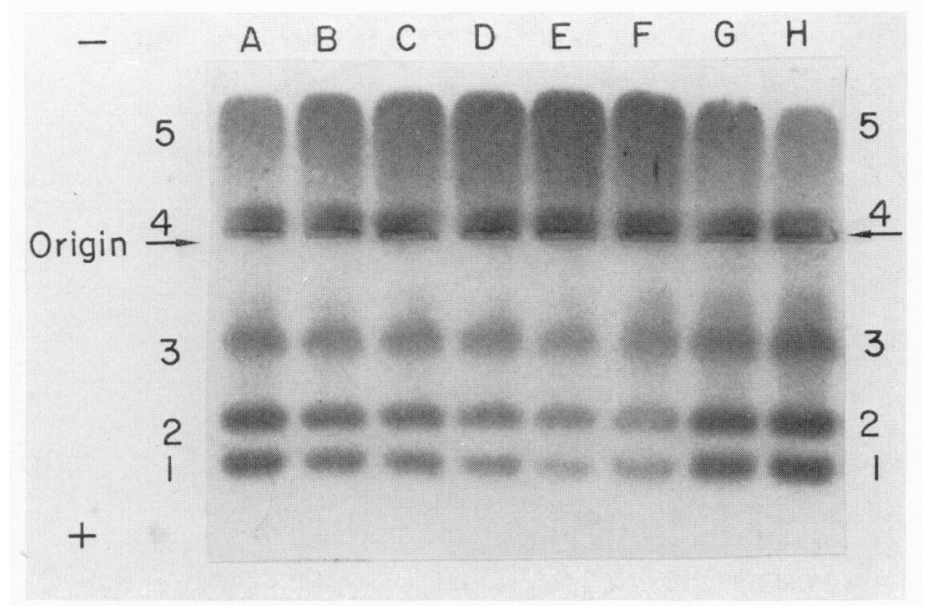

Electrophoretic patterns of LDH from rat uterus extracts. Numbers indicate the position of corresponding isoenzymes. A, control; B, 5-day pregnancy; C, 8-day pregnancy; D, 14-day pregnancy; E, 17-day pregnancy; F, 21-day pregnancy; G, 4 days post partum; $\mathrm{H}$, ovariectomized. All homogenates were diluted to obtain the same total enzymatic activity/volume of sample inserted. 
curves obtained by plotting relative activity against concentration of substrate clearly show the catalytic differences.

The behaviour of total $\mathrm{LDH}$ from crude tissue extracts was that expected

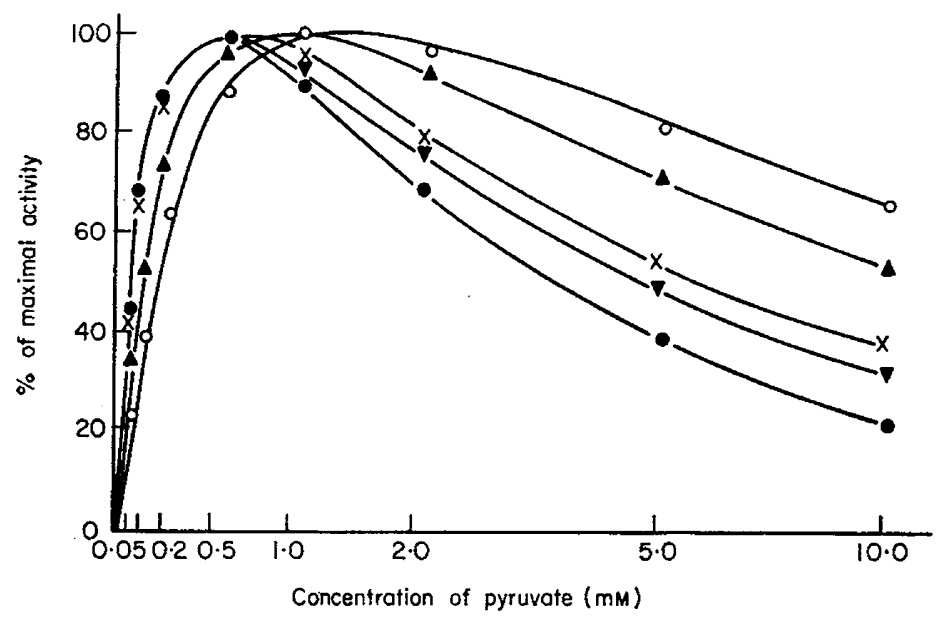

TEXT-FIG. 1. Effect of pyruvate concentration upon LDH activity. Initial reaction velocity, expressed as a percentage of the maximal activity, is plotted against concentration of pyruvate. Final concentration of NADH was $0.115 \mathrm{~mm}$, that of phosphate buffer, $\mathrm{pH} 7.4,80 \mathrm{~mm}$, and those of pyruvate, $0.05,0.1,0.2,0.5,1.0,2.0,5.0$ and $10.0 \mathrm{~mm}$. , LDH-1; 0 , LDH-5; $x$, uterine extract (control); $\Delta$, uterine extract (21st day of pregnancy); $\nabla$, uterus extract (20 days after ovariectomy). Each point represents the average value of nine determinations on different samples.

\section{TABLE 3}

RATIO OF LACTATE DEHYDROGENASE ACTIVITIES DETERMINED AT TWO PYRUVATE CONCENTRATIONS $(0.2 \mathrm{mM}$ AND $10 \mathrm{~mm})$

\begin{tabular}{|c|c|c|c|}
\hline Preparation assayed & $\begin{array}{l}\text { No. of } \\
\text { cases }\end{array}$ & \multicolumn{2}{|c|}{ Ratio } \\
\hline $\begin{array}{l}\text { Purified LDH-1 } \\
\text { Purified LDH-5 } \\
\text { Liver extract } \\
\text { Heart extract } \\
\text { Kidney extract }\end{array}$ & $\begin{array}{l}5 \\
5 \\
5 \\
5 \\
5\end{array}$ & $\begin{array}{l}2.71 \pm 0.14 \\
0.95 \pm 0.08 \\
0.99 \pm 0.10 \\
2.60 \pm 0.14 \\
2.48 \pm 0.10\end{array}$ & \\
\hline $\begin{array}{l}\text { Uterus extract } \\
\text { Control } \\
\text { 5-day pregnancy } \\
\text { 8-day pregnancy } \\
\text { 14-day pregnancy } \\
\text { 17-day pregnancy } \\
\text { 21-day pregnancy } \\
\text { 4 days post partum }\end{array}$ & $\begin{array}{l}25 \\
10 \\
10 \\
10 \\
10 \\
10 \\
10\end{array}$ & $\begin{array}{l}2.10 \pm 0.10 \\
1.95 \pm 0.07 \\
1.72 \pm 0.13 \\
1.40 \pm 0.09 \\
1.36 \pm 0.11 \\
1.33 \pm 0.09 \\
1.98 \pm 0.12\end{array}$ & $\begin{array}{l}P<0.01 \\
P<0.01 \\
P<0.01 \\
P<0.01 \\
P<0.01\end{array}$ \\
\hline Ovariectomized & 5 & $2.27 \pm 0.06$ & $P<0.01$ \\
\hline
\end{tabular}

from the relative isoenzymic composition. Skeletal muscle and liver extracts gave low/high substrate activity ratios and curves of activity against concentration of pyruvate almost identical to those of $\mathrm{LDH}-5$, while those for heart and kidney were similar to that of LDH-1 (Table 3). When uterine extracts were 
studied, there were modifications of low/high substrate activity ratios and of the shape of the curves of activity plotted against concentration of pyruvate during the course of pregnancy. These modifications were in complete agreement with those expected from the changes observed in isoenzymic patterns.

Ovariectomy, on the other side, also produced modifications of the ratio and curve as expected from the relative increase of LDH-1 and -2 isoenzymes.

\section{DISGUSSION}

It is evident that there is a rise in the uterine $\mathrm{LDH}$ activity during pregnancy. This increase has been shown to be due exclusively to the increment of Isoenzymes 4 and 5, a finding which indicates an activation of the synthesis of A or 'muscle type' polypeptide units.

The factors involved in the regulation of the activity of genes for A and B chains are not well understood. Some findings have indicated a rôle for oxygen tension in the selective production of those units (Goodfriend, Sokol \& Kaplan, 1966). On the other hand, Goodfriend \& Kaplan (1964) demonstrated that oestradiol selectively induced synthesis of $\mathrm{A}$ polypeptides in the uterus of immature rats.

The results of ovariectomy presented here indicate that ovarian hormones are necessary for the activation of the gene for A monomers in the uterus. The increased production of those units during pregnancy is, very probably, dependent on hormonal factors.

Another aspect of the problem is that of its functional significance. It is known that substrate- or product-inhibition of the activity of isoenzymes may function as a regulatory mechanism (Kaplan et al., 1968). The acquisition of isoenzymes rich in A units (LDH-4 and -5) enables a tissue to transform pyruvate to lactate, even in the presence of high concentrations of both substances. This assures the oxidation of NADH and the functioning of the glycolytic pathway in anaerobiosis.

Changes demonstrated during pregnancy indicate a process of adjustment of the isoenzymic complement of the uterine tissue to the conditions prevailing during parturition.

This fact emphasizes the great functional flexibility afforded to an organ by the possibility of regulating the synthesis of multiple molecular forms of an enzyme in order to meet its changing metabolic needs.

\section{AGKNOWLEDGMENT}

This work has been supported by a grant from the Consejo Nacional de Investigaciones Científicas y Técnicas (Argentina) (3488/69).

\section{REFERENCES}

Battellino, L. J., Ramos Jame, F. \& Blanco, A. (1968) Kinetic properties of rabbit testicular lactate dehydrogenase isozyme. F. biol. Chem. 243, 5185.

Biron, P. (1964) Effect of pregnancy on uterine lactate dehydrogenase isoenzymes. Revue can. Biol. 23, 497.

Blanco, A., Zinkham, W. H. \& Kupchyk, L. (1964) Genetic control and ontogeny of lactate dehydrogenase in pigeon testes. F. exp. Zool. 156, 137. 
Cahn, R., Kaplan, N. O., Levine, L. \& Zwilling, E. (1962) Nature and development of lactic dehydrogenases. Science, $\mathcal{N} . \Upsilon$. 136, 962.

Goodfriend, T. L. \& KAPLAN, N. O. (1964) Effects of hormone administration on lactic dehydrogenase. 7. biol. Chem. 239, 130.

Goodrriend, T. L., Sokol, D. M. \& Kaplan, N. O. (1966) Control of synthesis of lactic acid dehydrogenases. F. molec. Biol. 15, 8.

Johnson, E. M. (1964) Quantification of enzyme activity subsequent to zone electrophoresis in starch gel. Analyt. Biochem. 8, 210.

Kaplan, N. O., Everse, J. \& Admiraat, J. (1968) Significance of substrate inhibition of dehydrogenases. Ann. N.Y. Acad. Sci. 151, 400.

Lowry, O. H., Rosebrovgh, N., Farr, A. \& Randall, R. (1951) Protein measurement with the Folin phenol reagent. F. biol. Chem. 193, 265.

Markert, C. I. (1962) Isozymes in kidney development. In: Proceedings of the 13th Annual Conference on the Kidney: Heredity, Developmental and Immunological Aspects of Kidney Diseases. Ed. J. Metcoff, Northwestern University Press, Evanston, Illinois.

MARKERT, G. L. (1963) Lactic dehydrogenase isozymes: dissociation and recombination of subunits. Science, N.Y. 140, 1329.

Markert, C. L. (1968) The molecular basis for isozymes. Ann. N.Y. Acad. Sci. 151, 14.

Plagemann, P. G. W., Gregory, K. F. \& Wróblewskr, F. (1960) The electrophoretically distinct forms of mammalian lactic dehydrogenase. II. Properties and interrelationships of rabbit and human lactic dehydrogenase isozymes. 7. biol. Chem. 235, 2288.

Richterich, R., Schafroth, P., AEbi, H. \& Vogdt, I. (1963) A study of lactic dehydrogenase isozyme pattern of human tissues by adsorption-elution on Sephadex-DEAE. Clinica chim. Acta, 8, 178.

SмIтнIEs, O. (1959) An improved procedure for starch-gel electrophoresis: further variations in the serum of normal individuals. Biochem. F. 71, 585 .

Stambaugh, R. \& Post, D. (1966) Substrate and product inhibition of rabbit muscle lactic dehydrogenase heart $\left(\mathrm{H}_{4}\right)$ and muscle $\left(\mathrm{M}_{4}\right)$ isozymes. F. biol. Chem. 241, 1462.

Wróblewski, F. \& La Due, J. S. (1955) Lactic dehydrogenase activity in blood. Proc. Soc. exp. Biol. Med. 90, 210. 